DOI 10.31558/2519-2949.2021.1.2

УДК 342.8

ORCID ID: https://orcid.org/0000-0003-4428-3981

Дем'яненко О. О., Черкаський національний університет

імені Богдана Хмельницького

\title{
ПРОПОРЦЙНА ВИБОРЧА СИСТЕМА 3 ВІДКРИТИМИ СПИСКАМИ: АНАЛІЗ НА ПРИКЛАДІ РЕЗУЛЬТАТІВ ВИБОРІВ ДО ЧЕРКАСЬКОЇ МІСЬКОЇ РАДИ
}

На основі аналізу виборчої системи, що застосовувалася на місиевих виборах у громадах з чисельністю вибориів понад 10 тисяч на прикладі результатів виборів до Черкаської міської ради виокремлено основні наслідки застосування нового виборчого законодавства при формуванні депутатського корпусу: пропориійна система з відкритими списками не практичі не передбачила значного впливу вибориів на формування місиевої ради внаслідок закріплення гарантованого мандату, застосування додаткового кваліфікачійного бар'єру, а також розподілу мандатів в єдиному виборчому списку без урахування преферениій вибориів. Наслідком стало те, що більшість депутатів міської ради отримали мандати за єдиним партійним списком і не були обрані в округах; прохідне місие в єдиному партійному списку забезпечило мандат кандидатам у депутати, які отримали мінімальну підтримку вибориів; гендерна квота в територіальному та єдиному виборчому списку посприяла збільшенню кількості жінок у Черкаській міській раді. Мета статті - проаналізувати пропориійну виборчу систему з відкритими списками на прикладі виборів до Черкаської міської ради. Відповідно до мети, авторкою було проаналізовано питання формування територіальних виборчих округів, списки політичних партій, що взяли участь у виборах депутатів Черкаської міської ради та подолали 5\%-й загороджувальний бар'єр, а також офічійні результати виборів депутатів Черкаської міської ради в територіальних виборчих округах та виілому по місту, розміщені на сайті Центральної виборчої комісії. На основі норм Виборчого кодексу, щзо регулюють питання встановлення результатів голосування та розподілу депутатських мандатів, визначено два типи кандидатів - новообраних депутатів Черкаської міської ради: ті, хто отримав мандат завдяки підтримиі вибориів; ті, хто отримав мандат завдяки місию в пермій n'ятіриі єдиного списку політичної партії. Також виокремлено тих кандидатів, хто не отримав мандат, проте здобув значну електоральну підтримку.

Ключові слова: виборча квота, гендерна квота, політична партія, кандидат у депутати.

Вибори в Україні є основною формою народного волевиявлення, способом безпосереднього здійснення влади Українським народом [1]. Саме через виборність втілюється ідея народного суверенітету і представництва всіх соціальних груп в системі влади.

У експертному середовищі тривалий час велася дискусія щодо кодифікації українського виборчого законодавства. За їі результатами 19 грудня 2019 року Верховною Радою України було прийнято Виборчий кодекс України. Проте, вже 16 липня 2020 року у його текст було внесено значну кількість змін - у понад 200 статей з 289 (законопроект 3485). 21 липня цей закон було підписано Президентом і опубліковано у «Голосі України» 22 липня 2020 року.

У наукових колах політологи, соціологи, юристи продовжували дискусії щодо термінології, участі політичних партій у виборах депутатів всіх рівнів тощо. Проте «турбулентність» у затвердженні нового виборчого законодавства далася взнаки вже на перших етапах його реалізації. I хоча міжнародні стандарти забороняють вносити зміни до норм виборчого законодавства за рік до проведення самих виборів, проте колізії доводилося усувати вже в ході виборчої кампанії.

Одним із типів виборів, відповідно до ст. 3 Виборчого кодексу України, є місцеві вибори:

а) вибори депутатів Верховної Ради Автономної Республіки Крим;

б) вибори депутатів сільської, селищної, міської ради;

в) вибори сільського, селищного, міського голови;

г) вибори депутатів районної ради;

(C) Дем'яненко О. О., 2021 
г) вибори депутатів обласної ради;

д) вибори депутатів районної у місті ради (у містах, де утворені районні у місті ради) [1].

Питання організації та проведення місцевих виборів регулюється книгою 4 Виборчого кодексу України «Місцеві вибори».

Основні зміни, що були запроваджені новим виборчим законодавством щодо місцевих виборів, наступні:

- 3 питань діяльності Центральної виборчої комісії, функціонування Державного реєстру виборців, притягнення до адміністративної та кримінальної відповідальності за правопорушення під час виборчого процесу;

- змінено строки декларування майнового стану, доходів, витрат і зобов'язань фінансового характеру кандидатами на виборні посади;

- запроваджено обмеження для одночасного балотування на місцевих виборах;

- змінено квоти при формуванні територіальних виборчих та дільничних комісій;

- закріплено гендерну квоту та впроваджено санкції за недотримання іiі при формуванні виборчих списків політичними партіями;

- змінено порядок відкликання депутата місцевої ради за народною ініціативою;

- посилено відповідальність за злочини у сфері виборів та ін.

25 жовтня 2020 року в Україні відбулися місцеві вибори, за результатами яких сформовані нові ради на рівні громад, районів, областей. Фактично місцеві вибори відбулися із одночасним застосуванням чотирьох різних виборчих систем. Мажоритарна система відносної більшості використовувалася на виборах голів громад з кількістю виборців до 75 тисяч осіб. За мажоритарною системою абсолютної більшості обиралися голови громад з кількістю виборців понад 75 тисяч осіб. Місцеві ради громад із кількістю виборців до 10 тисяч осіб формувалися за мажоритарною системою відносної з голосуванням в багатомандатних округах. Місцеві ради громад 3 кількістю виборців понад 10 тисяч осіб, а також районні та обласні ради формувалися на основі пропорційної системи з відкритими списками.

У зв’язку зі зміною виборчого законодавства та складністю останньої з перелічених виборчих систем, значний науковий інтерес становить достеменний аналіз підсумків виборчого процесу у великих громадах, на рівні районів та областей, а також практичного застосування норм Виборчого кодексу та його наслідки при формуванні депутатського корпусу місцевих рад.

Об'єктом дослідження стала виборча система, що застосовувалася для формування Черкаської міської ради (громада з кількістю виборців майже 225 тисяч осіб) та результати виборів до неї.

Оскільки місцеві вибори відбувалися зовсім нещодавно та за новим виборчим законодавством, наукова політологічна література з цієї проблематики поки що відсутня, і дане дослідження претендує на першість у відповідній науковій сфері.

Метою статті є аналіз пропорційної виборчої системи з відкритими списками на прикладі виборів до Черкаської міської ради.

Відповідно до ст. 197 Виборчого кодексу України (далі - ВК), склад Черкаської міської ради 42 депутати [1]. Територіальна організація виборів до неї передбачала формування територіальних виборчих округів (єдиний багатомандатний виборчий округ - вся територія міста, виборчі дільниці були утворені постановою Центральної виборчої комісії № 117 від 25 червня 2020 р.)

Відповідно до п. 4 ст. 201 Виборчого кодексу України, орієнтовна кількість територіальних округів визначається як ціла частка від ділення кількісного складу відповідної ради на 10. При утворенні цих округів відхилення від їх середньої орієнтовної кількості не може становити більше ніж два округи [1]. Тобто, 42:10=4,2. Отже, в межах Черкаської громади могло бути утворено від 4 до 6 територіальних виборчих округів (далі - ТВО).

На основі цих норм законодавства, Черкаська міська територіальна виборча комісія утворила 6 ТВО. Незважаючи на відсутність чітких норм, що регламентували б порядок утворення таких округів з точки зору рівномірності розподілу виборців у їх межах, ТВО у Черкаській громаді були утворені приблизно однакові за розміром. Так, округ №1 налічував 35767 виборців, округ №2 - 37112, округ №3 - 37143, округ №4 - 33488, округ №5 - 34824, округ №6 - 34072 виборців [3].

У виборах депутатів Черкаської міської ради участь взяли 20 політичних партій, які висунули кандидатами у депутати 737 осіб. Проте, можливість отримати депутатські мандати отримали лише ті політичні сили, що подолали 5\% бар'єр, тобто набрали 5 і більше відсотків голосів виборців, які прийшли на виборчу дільницю і проголосували (п. 3 ст. 256 ВК). Таких партій налічується 7. 
Офіційні їх результати наступні:

«За майбутнє»-14,11\%, що означає отримання 8 депутатських мандатів,

«Слуга народу» - 13,91\%, тобто 8 депутатів,

«Европейська солідарність» - 13,24\%, 7 депутатів,

«Голос» - 11,04\%, 6 депутатів

ВО «Черкащани» - 9, $16 \%, 5$ депутатів,

ВО «Батьківщина» $-6,19 \%, 4$ депутати,

«Опозиційна платформа - За життя» - 6,96\%, 4 депутати [4].

Таблиия 1

Результати виборів до Черкаської міської ради

\begin{tabular}{|c|c|c|c|c|}
\hline № & $\begin{array}{c}\text { Назва політичної партї̈, місцева організація якої висунула } \\
\text { кандидатів у депутати }\end{array}$ & $\begin{array}{c}\text { К-сть } \\
\text { голосів, } \\
\text { поданих } \\
\text { за місцеву } \\
\text { організа-цію } \\
\text { політичної } \\
\text { партії }\end{array}$ & $\begin{array}{c}\text { \% голосів, } \\
\text { поданих } \\
\text { за місцеву } \\
\text { організа- } \\
\text { цію ПП }\end{array}$ & $\begin{array}{c}\text { K-сть } \\
\text { отрима } \\
\text { них } \\
\text { депy- } \\
\text { тат- } \\
\text { ських } \\
\text { манда- } \\
\text { тів }\end{array}$ \\
\hline 1. & Політична партія "ЗА МАЙБУТНЄ" & 8555 & 14,1 & 8 \\
\hline 2. & Політична партія "СЛУГА НАРОДУ" & 8431 & 13,9 & 8 \\
\hline 3. & Політична партія "СВРОПЕЙСЬКА СОЛІДАРНІСТЬ" & 8029 & 13,2 & 7 \\
\hline 4. & Політична партія "ГОЛОС" & 6694 & 11,0 & 6 \\
\hline 5. & $\begin{array}{l}\text { Політична партія Всеукраїнське об’єднання } \\
\text { "ЧЕРКАЩАНИ" }\end{array}$ & 5557 & 9,2 & 5 \\
\hline 6. & $\begin{array}{l}\text { Політична партія "ОПОЗИЦІЙНА ПЛАТФОРМА - ЗА } \\
\text { ЖИТТЯ" }\end{array}$ & 4221 & 7,0 & 4 \\
\hline 7. & $\begin{array}{l}\text { Політична партія Всеукраїнське об’єднання } \\
\text { "БАТЬКІВЩИНА" }\end{array}$ & 3752 & 6,2 & 4 \\
\hline 8. & Політична партія "НАЦІОНАЛЬНИЙ КОРПУС" & 2755 & 4,5 & 0 \\
\hline 9. & Політична партія "ПАРТІЯ ВІЛЬНИХ ДЕМОКРАТІВ" & 2365 & 3,9 & 0 \\
\hline 10. & Політична партія Всеукраїнське об’єднання "СВОБОДА" & 1555 & 2,6 & 0 \\
\hline 11. & Політична партія "ПЕРЕМОГА ПАЛЬЧЕВСЬКОГО" & 1532 & 2,5 & 0 \\
\hline 12. & Політична партія "СИЛА ЧЕСТЬ" & 1518 & 2,5 & 0 \\
\hline 13. & Політична партія "НАШ КРАЙ" & 1491 & 2,5 & 0 \\
\hline 14. & Політична партія "ПРОПОЗИЦІЯ" & 1045 & 1,7 & 0 \\
\hline 15. & Партія ветеранів Афганістану & 975 & 1,6 & 0 \\
\hline 16. & Політична партія "ОБ’ЄДНАННЯ "САМОПОМІЧ" & 626 & 1,0 & 0 \\
\hline 17. & Політична партія "ДЕМОКРАТИЧНА СОКИРА" & 546 & 0,9 & 0 \\
\hline 18. & $\begin{array}{l}\text { Політична партія "КОМАНДА СЕРГІЯ РУДИКА. ЧАС } \\
\text { ЗМІН!" }\end{array}$ & 504 & 0,8 & 0 \\
\hline 19 & Політична партія "ОШУКАНІ УКРАЇНЦІ" & 249 & 0,4 & 0 \\
\hline 20. & $\begin{array}{l}\text { Політична партія "СОЦІАЛІСТИЧНА ПАРТІЯ } \\
\text { ОЛЕКСАНДРА МОРОЗА" }\end{array}$ & 205 & 0,3 & 0 \\
\hline
\end{tabular}

Джерело: складено автором.

Відповідно до п. 1 ст. 260 Виборчого кодексу, місцева організація політичної партії, партія, яка отримала право на участь у розподілі депутатських мандатів на відповідних місцевих виборах, гарантовано отримує один депутатський мандат, який розподіляється в порядку черговості відповідно до затвердженого партією єдиного виборчого списку [1].

Отже, перший номер єдиного списку кожної 3 цих 7 партій автоматично отримав мандат. Це - Бондаренко А. В. («За майбутнє»), Мойсієнко В. М. («Слуга народу»), Кудактін С. В. («Європейська солідарність»), Євпак В. М. («Голос»), Беззубенко В. А. (ВО «Черкащани»), Діскант Р. В. (ВО «Батьківщина»), Кашко О. М. («Опозиційна платформа - За життя»). 
Решта, а це 35 мандатів, розподілялися спочатку в територіальних виборчих округах. Як уже було сказано, м. Черкаси, відповідно до ст. 198 ВК, було поділене на 6 ТВО, у кожному з яких кожна партія висунула від 5 до 12 кандидатів. Для отримання 1 депутатського мандату виборчий список партії у кожному окрузі мав набрати виборчу квоту, 2 місця - дві виборчі квоти і так далі.

Відповідно до визначення, запропонованого у статті 257 Виборчого кодексу України, виборча квота - це кількість голосів виборців, необхідних для отримання одного депутатського мандата. Виборча квота обчислюється як ціла частина результату ділення загальної кількості голосів, поданих на підтримку усіх територіальних виборчих списків організацій партій, які мають право на участь у розподілі депутатських мандатів, встановленої відповідно до частини другої ст. 257 кодексу, на кількість депутатських мандатів, встановлену шляхом віднімання від кількісного складу Верховної Ради Автономної Республіки Крим, обласної, районної, районної у місті, а також міської, сільської, селищної ради (територіальної громади з кількістю виборців 10 тисяч і більше), сумарної кількості гарантованих для кожної партії мандатів відповідно до ч. 1 ст. 260 Кодексу [1].

У виборах депутатів Черкаської міської ради участь взяли 60605 мешканців міста Черкаси. Партії, що подолали 5\%-й бар'єр, отримали 45239 голосів, що при поділі на 35 нерозподілених мандатів дає цифру 1292. Отже, за результатами виборів до Черкаської міської ради виборча квота склала 1292 голоси. Голоси, віддані за решту - 13 партій, при визначенні виборчої квоти та подальшому розподілі мандатів взагалі не враховувалися.

Партійне завдання кожного територіального виборчого списку у кожному окрузі полягало у тому, щоб всім разом набрати хоча б одну виборчу квоту. В той же час, завданням найамбітніших кандидатів та кандидаток у цих списках було отримати персонально за себе $25 \%$ виборчої квоти. У нашому випадку мова йде про 323 голоси і більше.

Причина цього - у нормах статті 259 Виборчого кодексу, відповідно до якої кандидати у депутати, які отримали кількість голосів виборців, яка дорівнює або перевищує 25 відсотків розміру виборчої квоти, розміщуються на початку територіального виборчого списку відповідної організації партії. Після них у територіальному виборчому списку розміщуються інші кандидати у черговості, визначеній організацією партії при висуванні кандидатів [1].

Отже, набрана в окрузі спільними зусиллями всіх кандидатів від однієї партії виборча квота забезпечує депутатський мандат першому номеру територіального списку. Набрані за себе $25 \%$ квоти дають можливість стати першим в цьому списку, змінити черговість розташування кандидатів у ньому і отримати депутатський мандат.

Тому, з одного боку, відомі та активні кандидати суттєво збільшили шанси партії отримати своїх представників у міській раді, а з іншого - якщо такий кандидат - не був першим номером в територіальному списку, то депутатом він міг і не стати. Ще один нюанс - якщо територіальний список партії у спільному підсумку в окрузі не набрав виборчу квоту - 1292 голоси - депутатом, обраним в територіальному окрузі, не став ніхто. Але всі ці голоси не були втрачені- вони «зараховувалися» в загальний результат партії і дали можливість кандидатам із єдиного списку партії отримати мандат.

Фактично, можна виокремити два типи кандидатів - новообраних депутатів:

1) ті, хто отримав мандат завдяки підтримці виборців;

2) ті, хто отримав мандат завдяки місцю в першій п’ятірці єдиного списку політичної партії.

Щодо перших, то безумовним лідером електоральних симпатій став кандидат від партії «Слуга народу» Мкртчян А. Р., якого підтримали 1008 черкащан. Відповідно, 3 другого номера в територіальному списку він став першим та, оскільки виборча квота територіальним списком партії в окрузі була набрана, отримав депутатський мандат.

Наступним у цьому переліку є кандидат від партії «Європейська солідарність» Рубан С. Л., за якого проголосували 762 виборця. Він був першим номером в територіальному виборчому списку партії, квота на цьому окрузі була набрана.

Третій за рівнем підтримки черкащан став Тренкін Ю. В., кандидат у депутати від політичної партії «ВО «Батьківщина», з результатом у 751 голос. Проте, депутатський мандат він отримав не завдяки такій електоральній підтримці, адже квота в окрузі територіальним списком партії набрана не була. Статус депутата Тренкін Ю.В. отримав, оскільки був другим номером у єдиному списку партії.

3-поміж тих кандидатів, що набрали від 500 до 700 голосів виборців, свої мандати як представники округу отримали Моторний Р. В., «За майбутнє» (651 голос), Батир Р. А., «Європейська солідарність» (584 голоси), Савенко О. С., «СС» (573 голоси), Красюк В. А., «СС» (512 голосів). 
Водночас, Мельник О. О., ВО «Батьківщина», з результатом у 564 голоси та Сухарьков I. В., ВО «Черкащани» - 582 голоси, стануть депутатами завдяки прохідному місцю в єдиному списку партії. На їхніх округах виборча квота територіальним списком набрана не була (табл. 2).

Таблиця 2

\section{Результати кандидатів у депутати Черкаської міської ради, що отримали найбільшу електоральну підтримку та мандат}

\begin{tabular}{|c|l|l|c|c|}
\hline № & $\begin{array}{c}\text { ПІП кандидата, що } \\
\text { отримав мандат } \\
\text { депутата Черкаської } \\
\text { міської ради }\end{array}$ & $\begin{array}{c}\text { К-сть } \\
\text { отриманих } \\
\text { голосів } \\
\text { виборців }\end{array}$ & $\begin{array}{c}\text { \% від } \\
\text { виборчой } \\
\text { квотии }\end{array}$ \\
\hline 1. & Мкртчян А. Р. & «Слуга народу» & 1008 & 78,01 \\
\hline 2. & Рубан С. Л. & «Свропейська солідарність» & 762 & 58,97 \\
\hline 3. & Тренкін Ю. В. & ВО «Батьківщина» & 751 & 58,12 \\
\hline 4. & Моторний Р. В. & «За майбутнє» & 651 & 50,38 \\
\hline 5. & Батир Р. А. & «Свропейська солідарність» & 584 & 45,2 \\
\hline 6. & Сухарьков І. В. & ВО «Черкащани» & 582 & 45,04 \\
\hline 7. & Савенко О. С. & «Свропейська солідарність» & 573 & 44,34 \\
\hline 8. & Мельник О. О. & ВО «Батьківщина» & 564 & 43,65 \\
\hline 9. & Красюк В. А. & «Свропейська солідарність» & 512 & 39,62 \\
\hline
\end{tabular}

Джерело: складено автором за: Обрані на відповідних виборах депутати місиевої ради.

Черкаський p-н, Черкаська міська рада URL: https://www.cvk.gov.ua/pls/vm2020/pvm057pid112= 30pid102 $=7772$ pf7691 $=63774$ pt001f01 $=695 \mathrm{rej}=0 \mathrm{pt00} \_\mathrm{t} 001 \mathrm{f01}=695 . \mathrm{html}$

При цьому, через ту ж таки не набрану в окрузі виборчу квоту, мандати не отримали такі кандидати в депутати як Міняйло О. О., «Голос» (562 голоси), Зоря Р. С., ВО «Черкащани» (499 голосів), Гордієнко В. С., «Слуга народу» (391 голос), Личко Д. Ю., «Європейська солідарність» (363 голоси).

Терьохін В. О., «За майбутнє» (445 голосів) - хоч і був першим номером в територіальному списку та набрав 34,4\% виборчої квоти, проте поступився однопартійцю Гладкому Г. А. на 46 голосів, тому також мандат депутата Черкаської міської ради не отримав. Поступився однопартійцю в окрузі й Радуцький О. Р., «Європейська солідарність» (462 голоси), тому не отримав статус депутата міської ради. Детально результати кожного з перерахованих кандидатів наведені у табл. 3.

Табличя 3 Результати кандидатів у депутати Черкаської міської ради,
що набрали $25 \%$ виборчої квоти і не отримали мандат

\begin{tabular}{|c|l|l|c|c|}
\hline № & \multicolumn{1}{|c|}{ ПІП кандидата } & \multicolumn{1}{|c|}{$\begin{array}{c}\text { Політична партія } \\
\text { отриманих } \\
\text { zолосів } \\
\text { виборців }\end{array}$} & $\begin{array}{c}\text { \% вid } \\
\text { виборчӧ̈ } \\
\text { квоти }\end{array}$ \\
\hline 1. & Міняйло О. О. & «Голос» & 562 & 43,49 \\
\hline 2. & Зоря Р. С. & ВО «Черкащани» & 499 & 38,62 \\
\hline 3. & Радуцький О. Р. & «Свропейська солідарність» & 462 & 35,75 \\
\hline 4. & Терьохін В. О. & «За майбутнє» & 445 & 34,44 \\
\hline 5. & Гордієнко В. С. & «Слуга народу» & 391 & 30,26 \\
\hline 6. & Личко Д. Ю. & «Свропейська солідарність» & 363 & 28,09 \\
\hline
\end{tabular}

Джерело: складено автором за: Виборчі списки кандидатів у депутати місиевої ради. Черкаська область. Черкаська міська рада URL: https://www.cvk.gov.ua/pls/vm2020/pvm056pid102=7772pf7691= 63774pt001f01=695rej=0pt00_t001f01=695.html\#52 
Загалом, в територіальних виборчих округах обрано було 13 депутатів Черкаської міської ради. 3 розподілом на партії цей список виглядає так:

Політична партія «За майбутнє» - 5 депутатів

Моторний Р. В. (651 голос) - 1 номер в 5 окрузі;

Гладкий Г. А. (491 голос) - отримав $38 \%$ виборчої квоти в 2 окрузі;

Агапова О. М. (382 голоси) - отримала 29,6\% виборчої квоти в 3 окрузі;

Майборода Л. В. (346 голосів) - отримала 26,8\% виборчої квоти в 6 окрузі;

Тронц Т. В. (178 голосів) - 1 номер в 1 окрузі.

Політична партія «Слуга народу» - 4 депутати

Мкртчян А. Р. (1008 голосів) - отримав 78\% виборчої квоти у 2 окрузі;

Волошин А. І. (455 голосів) - 1 номер в 3 окрузі;

Котолуп Ю. Ю. (420 голосів) - отримав $32,5 \%$ виборчої квоти у 1 окрузі;

Дудка С. В. (241 голос) - 1 номер в 4 окрузі.

Політична партія «Европейська солідарність»- 4 депутати

Рубан С. Л. (762 голоси) - 1 номер в 4 окрузі;

Батир Р. А. (584 голоси) - 1 номер в 5 окрузі;

Савенко О. С. (573 голоси) - 1 номер в 3 окрузі;

Красюк В. А. (512 голосів) - 1 номер в 1 окрузі.

Тобто, з 13 обраних в округах депутатів Черкаської міської ради, лише 5 змогли набрати 25\% і більше виборчої квоти, щоб просунутися по територіальному списку.

Водночас, ще 6 депутатів набрали понад 25\% квоти, але й одночасно були «перестраховані» партією першим місцем в територіальному списку.

Решта депутатських мандатів із загального складу Черкаської міської ради - а це ще 22, розподілялися партіями за єдиними списками, де кількість голосів виборців, відданих за кандидата, вже не має жодного значення. Лише черговість розташування, визначена партією напередодні виборів.

Відповідно, у Черкаській міській раді окремі кандидати у депутати отримали мандати, при цьому за результатами голосування не здобули підтримки навіть 100 виборців.

Зокрема, це Темченко Ю. С., ВО «Батьківщина» - 37 голосів, Саліна Ю. І., ВО «Черкащани»40 голосів, Прядка С. М., «Слуга народу» - 58 голосів, Буряк С. В., ВО «Черкащани» - 78 голосів, Абрамова К. С., «Слуга народу» - 89 голосів (табл. 4).

Таблиия 4

\section{Результати кандидатів у депутати Черкаської міської ради, що отримали мандат за сдиним багатомандатним виборчим округом з мінімальною кількістю голосів виборців}

\begin{tabular}{|c|c|c|c|c|}
\hline № & $\begin{array}{c}\text { ПІП кандидата, } \\
\text { що отримав мандат депутата } \\
\text { Черкаської міської ради }\end{array}$ & Політична партія & $\begin{array}{c}\text { К-сть } \\
\text { отриманих } \\
\text { голосів } \\
\text { виборців }\end{array}$ & $\begin{array}{l}\text { \% від } \\
\text { виборчоі } \\
\text { квоти }\end{array}$ \\
\hline 1. & Абрамова К. С. & «Слуга народу» & 89 & 6,88 \\
\hline 2. & Буряк С. В. & ВО «Черкащани» & 78 & 6,03 \\
\hline 3. & Прядка С. М. & «Слуга народу» & 58 & 4,48 \\
\hline 4. & Саліна Ю. І. & ВО «Черкащани» & 40 & 3,09 \\
\hline 5. & Темченко Ю. С. & ВО «Батьківщина» & 37 & 2,86 \\
\hline
\end{tabular}

Джерело: складено автором за: Обрані на відповідних виборах депутати місиевої ради. Черкаський р-н, Черкаська міська рада URL: https://www.cvk.gov.ua/pls/vm2020/pvm057pid112= 30pid102 $=7772$ pf7691 $=63774$ pt001 f01 $=695 \mathrm{rej}=0 \mathrm{pt00} \_\mathrm{t} 001 \mathrm{f01}=695 . \mathrm{html}$

Решта новообраних депутатів-єдиносписочників отримали від 140 до 751 голосу на свою підтримку. Результати кожного з них наведені у таблиці 5. 
Результати кандидатів у депутати Черкаської міської ради, що отримали мандат за сдиним багатомандатним виборчим округом

\begin{tabular}{|c|c|c|c|c|}
\hline № & ПІБ & Партія & $\begin{array}{c}\text { К-сть } \\
\text { голосів }\end{array}$ & $\begin{array}{c}\% \text { віd } \\
\text { квоти }\end{array}$ \\
\hline 1. & Тренкін Ю. В. & ВО «Батьківщина» & 751 & 58,12 \\
\hline 2. & Сухарьков І. В. & ВО «Черкащани» & 582 & 45,04 \\
\hline 3. & Мельник О. О. & ВО «Батьківщина» & 564 & 43,65 \\
\hline 4. & Казарян Н. П. & ВО «Черкащани» & 473 & 36,6 \\
\hline 5. & Шмиголь С. О. & «Голос» & 390 & 30,18 \\
\hline 6. & Валенчук П. П. & «Голос» & 302 & 23,37 \\
\hline 7. & Бандура I. В. & «Європейська солідарність» & 284 & 21,98 \\
\hline 8. & Левицький Я. С. & «Опозиційна платформа - За життя» & 282 & 21,82 \\
\hline 9. & Погостінська Ю. О. & «Опозиційна платформа - За життя» & 274 & 21,2 \\
\hline 10. & Івашкова Н. С. & «Голос» & 255 & 19,73 \\
\hline 11. & Друмашко В. Г. & «Голос» & 227 & 17,56 \\
\hline 12. & Шевченко Г. Ю. & «За майбутнє» & 180 & 9,28 \\
\hline 13. & Холупняк К. О. & «Голос» & 171 & 13,23 \\
\hline 14. & Замирайло О. А. & «Опозиційна платформа - За життя» & 162 & 12,53 \\
\hline 15. & Шабатура С. В. & «Європейська солідарність» & 156 & 12,07 \\
\hline 16. & Мушієк А. М. & «За майбутнє» & 152 & 11,76 \\
\hline 17. & Мелікова О. П. & «Слуга народу» & 140 & 10,83 \\
\hline
\end{tabular}

Джерело: складено автором за: Обрані на відповідних виборах депутати місиевої ради.

Черкаський p-н, Черкаська міська рада URL: https://www.cvk.gov.ua/pls/vm2020/pvm057pid112= 30 pid102 $=7772$ pf7691 $=63774$ pt001f01 $=695 \mathrm{rej}=0 \mathrm{pt00} \_t 001 \mathrm{f01}=695 . \mathrm{html}$

Висновки. Новим Виборчим кодексом України у процес проведення місцевих виборів у громадах 3 кількістю виборців понад 10 тисяч було запроваджено дві суттєві новації: застосування виборчої системи, яка дозволяє персоніфікувати голосування (пропорційна система $з$ відкритими списками); закріплення обов'язкової гендерної квоти та санкції за ії̈ недотримання.

На основі аналізу виборчих списків політичних партій, що взяли участь у виборах депутатів Черкаської міської ради, та результатів виборів, висновки застосування нової виборчої системи при формуванні цієї ради наступні:

1. Відкриті списки на практиці не стали дійсно відкритими, оскільки з 42 депутатів Черкаської міської ради:

- 7 - отримали мандат, тому що були першими в єдиному партійному списку, не балотувалися в територіальних виборчих округах;

- 11 - обрані виборцями в округах та отримали їх підтримку у кількості голосів, що перевищує $25 \%$ виборчої квоти;

- 2 - отримали мандати завдяки набраній спільними зоднопартійцями зусиллями всіх кандидатів територіального округу виборчої квоти;

- 22 - стали депутатами завдяки прохідному місцю в єдиному партійному списку, де місця розподілялися виключно по-порядку, незалежно від кількості отриманих голосів виборців.

Прохідне місце в єдиному партійному списку забезпечило мандат навіть тим кандидатам у депутати міської ради, які не отримали навіть 100 голосів на свою підтримку.

2. Зважаючи на рівномірність сформованих округів за кількістю виборців, можливість територіального виборчого списку набрати необхідну кількість голосів в кожному з них була однакова. Але на практиці вдалося це зробити не всім.

Конкурентність між потужними кандидатами від однієї партії в межах одного територіального виборчого округу суттєво збільшила кількість голосів, отриманих партією, проте не забезпечило мандат двом кандидатам від однієї партії в жодному окрузі міста. Це на практиці також доводить мінімальний вплив виборців на кінцевий результат виборів. 
В підсумку кандидати, які завчасно з'ясували всі «підводні камені» та були підстраховані партією першими номерами в територіальних списках і місцями в першій п'ятірці єдиного списку партії, однозначно отримали перевагу. Для решти кандидатів і кандидаток, а також їх виборців, нова виборча система стала повним розчаруванням.

3. Гендерна квота в територіальному та єдиному виборчому списку посприяла збільшенню кількості жінок у Черкаській міській раді - тепер їх 11, тобто 26\%. При цьому 9 з них - отримали мандат за єдиними виборчим списком i лише 2 - за результатами підтримки виборців в територіальних округах.

Отже, на практиці не відбулося реального впливу виборців на результати виборів, незважаючи на анонсовані відкриті списки, що такий вплив мали б передбачати. Основні причини цього закріплення гарантованого мандату (перший номер єдиного виборчого списку), застосування додаткового кваліфікаційного бар'єру (для просування у межах територіального виборчого списку кандидату у депутати Черкаської міської ради потрібно було набрати 25\% і більше виборчої квоти), а також розподілу мандатів в єдиному виборчому списку без урахування преференцій виборців.

Водночас, така пропорційна виборча система в частині правил формування єдиного та територіальних виборчих списків, а також принципу розподілу мандатів у єдиному виборчому списку, сприяла збільшенню представництва недопредставленої статі (у нашому випадку - жінок) серед депутатського корпусу місцевої ради.

Подальші наукові розвідки можуть бути пов'язані з більш глибокими дослідженнями впливу гендерного квотування у виборчих списках політичних партій на реальне представництво жінок та чоловіків у місцевих радах різного рівня.

\section{Бібліографічний список:}

1. Виборчий кодекс України. URL: https://zakon.rada.gov.ua/laws/show/396-20\#n4061

2. Виборчі списки кандидатів у депутати місцевої ради. Черкаська область. Черкаська міська рада URL: https://www.cvk.gov.ua/pls/vm2020/pvm056pid102=7772pf7691=63774pt001f01=695rej=0pt00_t001f01= 695.html\#52

3. Виборчі округи з виборів депутатів міських рад. Черкаська область. URL: https://www.cvk.gov.ua/ $\mathrm{pls} / \mathrm{vm} 2020 / \mathrm{pvm} 116 \mathrm{pt} 001 \mathrm{f} 01=695 \mathrm{pt} 00 \_\mathrm{t} 001 \mathrm{f} 01=695 \mathrm{pid} 112=2 \mathrm{pid} 100=71 \mathrm{pid} 102=7772 \mathrm{rej}=0 . \mathrm{html}$

4. Обрані на відповідних виборах депутати місцевої ради. Черкаський р-н, Черкаська міська рада URL: https://www.cvk.gov.ua/pls/vm2020/pvm057pid112=30pid102=7772pf7691=63774pt001f01=695rej= 0pt00_t001f01=695.html

\section{References:}

1. Vyborchyi kodeks Ukrainy. URL: https://zakon.rada.gov.ua/laws/show/396-20\#n4061

2. Vyborchi spysky kandydativ u deputaty mistsevoi rady. Cherkaska oblast. Cherkaska miska rada URL: https://www.cvk.gov.ua/pls/vm2020/pvm056pid102=7772pf7691=63774pt001f01=695rej=0pt00_t001f01= 695.html\#52

3. Vyborchi okruhy z vyboriv deputativ miskykh rad. Cherkaska oblast. URL: https://www.cvk.gov.ua/ $\mathrm{pls} / \mathrm{vm} 2020 / \mathrm{pvm} 116 \mathrm{pt} 001 \mathrm{f0}=695 \mathrm{pt} 00 \_\mathrm{t} 001 \mathrm{f0} 1=695 \mathrm{pid} 112=2 \mathrm{pid} 100=71 \mathrm{pid} 102=7772 \mathrm{rej}=0 . \mathrm{html}$

4. Obrani na vidpovidnykh vyborakh deputaty mistsevoi rady. Cherkaskyi r-n, Cherkaska miska rada URL: https://www.cvk.gov.ua/pls/vm2020/pvm057pid112=30pid102=7772pf7691=63774pt001f01=695rej= Opt00_t001f01=695.html

\section{Demianenko O. O. Proportional Electoral System with Open Lists: Analysis on the Example of Cherkasy City Council}

Based on the analysis of the electoral system used in local elections in communities with more than 10,000 voters, the main consequences of the application of the new electoral legislation in the formation of the deputy corps are highlighted on the example of Cherkasy City Council election results: in this proportional system with open lists voters could not influence the formation of the deputy corps of the Cherkasy City Council due to the consolidation of the guaranteed mandate, the application of an additional qualification barrier, as well as the distribution of mandates in a single electoral list without taking into account the preferences of voters.

It is proved that the lists of political parties have not become open in practice. It was found that most deputies of the city council received seats on a single party list, although they were not elected in the constituencies. It was found that the place in the top five in the single party list provided a mandate to those who received minimal voter support.

It was verified that competition between candidates from one party within one territorial constituency significantly increased the total number of votes per party, but did not secure a mandate for two candidates 
in any constituency in the city. It has been shown that the gender quota has contributed to an increase in the number of women in the Cherkasy City Council from 10 to $26 \%$.

The purpose of the article is to analyze the results of the elections to the Cherkasy City Council and to determine the main trends in the formation of the deputies on the basis of the Electoral Code of Ukraine.

In accordance with the purpose of the article, the author analyzed the lists of political parties that participated in the election of deputies to the Cherkasy City Council and overcame the 5\% barrier.

The official results of the Cherkasy City Council elections in the territorial constituencies and in the city as a whole were also analyzed.

Based on the norms of the Electoral Code, which regulate the establishment of voting results and distribution of parliamentary seats, two types of candidates have been identified-newly elected deputies of the Cherkasy City Council: those who received a mandate due to voter support; those who won a seat due to a place in the top five of the single list of a political party. Candidates who did not receive a mandate but received significant electoral support were also singled out.

Keywords: electoral quota, gender quota, political party, candidate. 